Int. J. Morphol.,

28(4):1221-1225, 2010.

\title{
Gross and Histologic Evaluation of Abdominal Adhesions Associated with Chromic Catgut and Polypropylene Sutured Enteropexies in Dog
}

\author{
Evaluación Macroscópica e Histológica de las Adherencias Abdominales Asociadas \\ a Enteropexias Suturadas con Catgut Crómico y Polipropileno en Perros
}

J. F. Akinrinmade \& A. O. Lawal

AKINRINMADE, J. F. \& LAWAL, A. O. Gross and histologic evaluation of abdominal adhesions associated with chromic catgut and polypropylene sutured enteropexies in dog. Int. J. Morphol., 28(4):1221-1225, 2010.

SUMMARY: The gross and histologic patterns of abdominal adhesions formed by the use of chromic catgut and polypropylene suture materials were evaluated in dogs. Gross and histologic examinations did not reveal significant difference ( $p>0.05)$ in the degree of adhesions observed at enteropexy sites in both suture materials. The use of polypropylene with superior suture qualities should be considered instead of chromic catgut for procedures in which adhesion is desired in the dog.

KEY WORDS: Adhesion; Chromic catgut; Polypropylene; Eneropexy.

\section{INTRODUCTION}

The formation of adhesions remains an inevitable sequela of any extensive abdominal and pelvic surgical procedures via the paramedian, ventral midline or flank incisions in both animal and human patients (Lipowitz \& Schnek, 1979; Liakakos et al., 2001).

Major causes have been implicated in the formation of intra-abdominal adhesions such as serosal trauma and inflammation, ischemic tissues, infections and foreign materials while rewarding measures that have been employed in its prevention included strict adherence to the principle of asepsis, atraumatic tissue handling and preservation of tissue viability and avoidance of spillage of abdominal contents (Baxter, 1991; Crowe \& Bjorling, 1993).

Severe unrelenting pain, peritonitis, intestinal abscess and obstruction are some of the complications that have attended abdominal surgery and attributed to postoperative adhesion (Henderson, 1993).

However, beneficial intentionally created adhesions have been employed as preventive or corrective means in certain procedures such as gastropexies, enteropexies, colopexies, herniorrhaphies and bladder retroflexion, to the delight of the surgeon.

Hitherto, chromic catgut has been the choice for such procedures in which adhesion is desired because of its presumed ability to elicit intense tissue inflammatory reactions and expectedly, stronger adhesion formation at the sutured site. This is despite setbacks such as high capillarity that promotes infection, poor knotting and knot insecurity, unreliable tensile strength and difficulty in handling (Bellinger, 1982; Bennet, 1988). On the other hand, newer, synthetic materials with superior suture characteristics and qualities are seldom considered for such procedures because of their minimal tissue reactivity.

There are various reports on the use of chromic catgut in procedures desirable of adhesion formation in some animal species (Bellinger; Bennett; Booth, 1998). However, there is paucity of efforts so far made to evaluate the prospects of the use of the newer, synthetic material with improved qualities in the same species and breed of dog. 
The present study therefore attempts to evaluate the gross and histologic patterns of abdominal adhesions formed with the use of chromic catgut and a monofilament, synthetic polypropylene suture material in dogs of the same litter.

\section{MATERIAL AND METHOD}

Six adult dogs comprised of three males and females respectively from the same litter and of the same breed, weighing $12.5-14.4 \mathrm{~kg}$, were used for the study. The animals were acclimatized and maintained on a standard diet. Baseline evaluations included physical examination, complete blood count $(\mathrm{CBC})$, serum biochemistry analysis, urinalysis and fecal examination for parasitic ova. All results were negative or within established reference ranges. Each dog was premedicated with atropine sulphate $(0.04 \mathrm{mg} / \mathrm{kg}$, im) and xylazine $(2 \mathrm{mg} / \mathrm{kg}, \mathrm{im})$. Anaesthesia was induced with thiopentone sodium $(10 \mathrm{mg} / \mathrm{kg}$ iv) and maintained with halothane and oxygen mixture. All dogs were administered a balanced electrolyte solution $(10 \mathrm{ml} / \mathrm{kg} / \mathrm{hr}$, iv) throughout the surgery.

Each dog was restrained on dorsal recumbency and aseptically prepared for ventral midline abdominal surgery. A ventral midline laparatomy incision was made for each of the animals to expose the abdominal cavity according to the technique described by Archibald (1984).

The jejunal segment of the small intestine was identified after a thorough examination of the entire abdomen confirmed absence of pathological abnormalities that may interfere with the study. With either 3-0 chromic catgut or polypropylene suture material, $4 \mathrm{~cm}$ section of the jejunum was sutured to the corresponding abdominal wall through the peritoneum and the transverse abdominal muscle longitudinally, with atraumatic needle using simple interrupted pattern.

To ensure standardization of the enterotomy, each bite was made equidistant from the other without penetrating the intestinal lumen and comprising of the same number. The procedure was repeated by making another enteropexy $1 \mathrm{~cm}$ caudal to the previous one and suturing by alternating the chromic catgut with polypropylene in a total of five enteropexies for the right and left abdominal wall respectively. Appropriate steps were taken to ensure atraumatic handling of tissues and minimize iatrogenic trauma and other complications.

A total of 10 enteropexy sites were created per dog and laparatomy incision was closed routinely according to the method described by Archibald. The dogs were closely monitored for between 7 and 30 days postoperation. They were euthanized 7,21 , and 30 days postoperation for groups 1,2 and 3 respectively and enteropexy sites harvested for histologic evaluation of each of chromic catgut and polypropylene sutured sites. Gross appearance and evaluation of pexy sites preceded harvest in all animals. All samples were initially preserved in $10 \%$ formalin and later embedded in paraffin for serial longitudinal sectioning and staining with Haematoxylin and Eosin (H\&E). The pexy sites were examined grossly and scored separately according to the degree of adhesion formed and the presence of wound complications, infections and pexy dehiscence using the method of Knightly et al. (1962) while histologic evaluation of inflammatory response and adhesion formation was done according to the technique of Woods et al. (1984). Using a four-point grading system:

Grade 1: Presence of inflammatory cellular infiltration with little evidence of fibroplasia.

Grade 2: Presence of less inflammatory cells and early evidence of fibroplasia.

Grade 3: Presence of decreasing inflammatory cells with strong presence of immature fibroplasia.

Grade 4: Presence of active, mature fibrocytes with little or no evidence of inflammatory cells.

\section{RESULTS}

The surgery was successful as no complications or any fatality was recorded with respect to all the dogs. Gross evaluation at necropsy revealed that healing progressed normally in all the dogs but had reached an advanced stage in group 3 dogs in both chromic catgut and polypropylene sutured pexies.

The average scores of the gross evaluation for the degree of adhesion at 7 days (group 1), 21 days (group 2) and 30 days (group 3 ) were $0.70,1.60$, and 2.40 respectively for chromic catgut sutured pexies while $0.6,1.75$ and 2.50 for groups 1,2 and 3 respectively were the scores for polypropylene (Table I).

Although, there was a progressive increase in the degree of adhesion formation with time in both treatment groups, there was however no significant difference $(\mathrm{P}>0.05$ observed grossly between the two treatment groups.

Histologic evaluation based on the degree of cellular inflammation and fibroplasia indicated histologic grades of groups 1, 2 and 3 ranged from 1-2 (mean 1.70), 2-4 mean 
(mean 3.45) and 3-4 (mean 3.70) respectively for chromic catgut sutured pexies and that of polypropylene ranged from 2-3 (mean 2.70), 3-4 (mean 3.55) and 3-4 (mean 3.80) for groups 1, 2 and 3 specimens respectively (Table II). Except only for the significantly higher $(\mathrm{P}<0.05)$ intensity of inflammatory cellular reaction observed in group 1 (7days) specimen of polypropylene sutured pexies, there was generally no significant difference in the gross appearance (Fig. 1) and histologic grades between chromic catgut and polypropylene sutured enteropexies (Figs. 2 and 3).

Table I. Gross appearance scores for chromic catgut and polypropylene suture pexies at 7, 21 and 30 days postoperation.

\begin{tabular}{llcc}
\hline & Mean & $\begin{array}{c}\text { Chromic catgut } \\
\text { pexy sutured }\end{array}$ & $\begin{array}{c}\text { Polypropylene } \\
\text { pexy sutured }\end{array}$ \\
\hline Group 1, 7days postop & Range & $0.7^{\mathrm{a}}$ & $0.6^{\mathrm{a}}$ \\
Group 2, 21 days postop & Mean & $0-1$ & $0-1$ \\
& Range & $1.60^{\mathrm{b}}$ & $1.75^{\mathrm{b}}$ \\
Group 3, 30 days postop & Mean & $1-2$ & $1-2$ \\
& Range & $2.40^{\mathrm{c}}$ & $2.50^{\mathrm{c}}$ \\
& & $2-3$ & $2-3$ \\
\hline
\end{tabular}

Table II. Histologic grades of chromic catgut and polypropylene sutured enteropexies at 7, 21, and 30 days postoperation.

\begin{tabular}{llcc}
\hline & Mean & $\begin{array}{c}\text { Chromic catgut } \\
\text { pexy sutured }\end{array}$ & $\begin{array}{c}\text { Polypropylene } \\
\text { pexy sutured }\end{array}$ \\
\hline Group 1, 7days postop & Range & $1.70^{\mathrm{a}}$ & $2.70^{\mathrm{a}}$ \\
& Mean & $1-2$ & $2-3$ \\
Group 2, 21 days postop & $3.45^{\mathrm{b}}$ & $3.55^{\mathrm{b}}$ \\
& Range & $2-4$ & $3-4$ \\
Group 3, 30 days postop & Mean & $3.70^{\mathrm{b}}$ & $3.80^{\mathrm{b}}$ \\
& Range & $3-4$ & $3-4$ \\
\hline
\end{tabular}

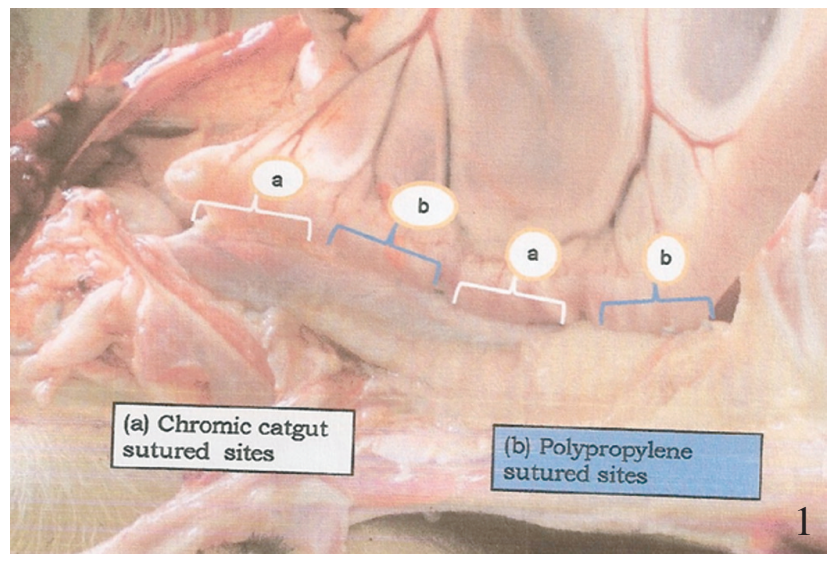

Fig. 1. Gross appearance of pexy sites at 21 days in both chromic and polypropylene treatments.

Fig. 2. Histologic features of chromic catgut sutured pexies at 30days.

Fig. 3. Comparable histologic features of polypropylene sutured pexies at 30 days showing matured fibrous connective tissues, maturing fibrocytes with less fibroblast cells.

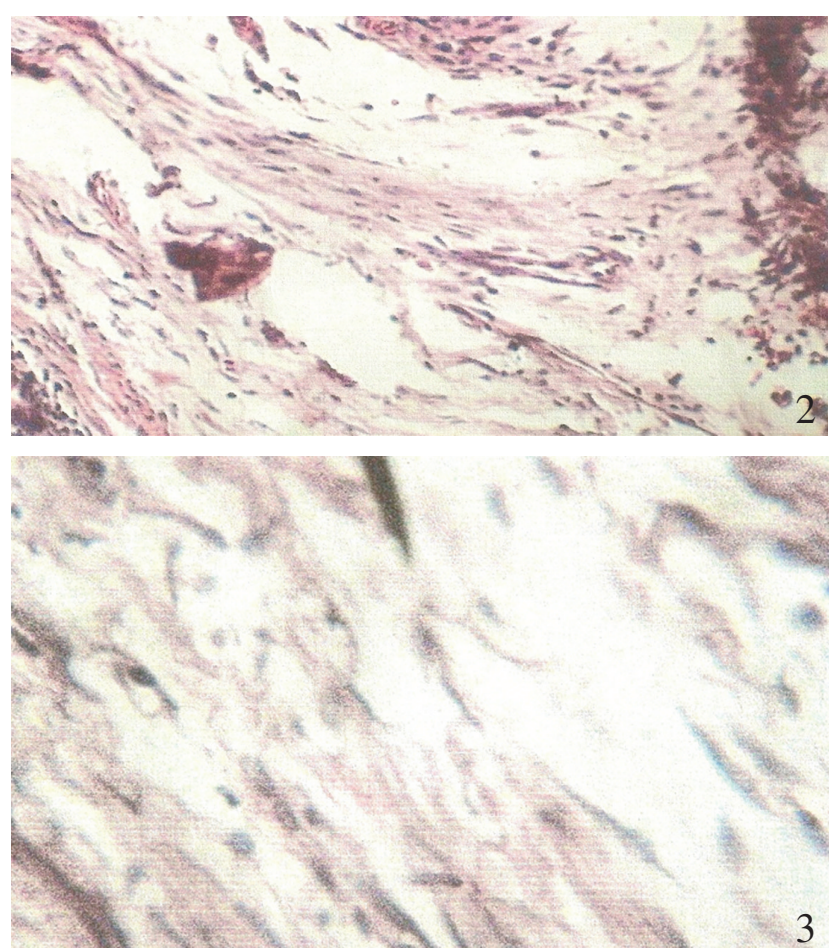




\section{DISCUSSION}

The formation of adhesion remains an inevitable sequela of any extensive abdominal and pelvic surgical procedures via the paramedian, ventral midline and flank incisions in both animals and humans (Monk et al., 1994; Liakakos et al.).

Clinical and autopsy studies in patients who had prior laparatomies had revealed a high incidence of intra-abdominal adhesions thus confirming the ease at which it occurs (Ellis, 1982; diZerega, 1997).

However, the creation of adhesion intentionally by surgeons is considered desirous and an important factor in the successful outcome of some procedures. Many factors have been documented in the pathogenesis of adhesion formation within and between abdominal structures (Henderson).

Of all these factors, ischemia arising from mechanical trauma associated with sutures and suturing is thought to play a major role in the determination of the quality of adhesion that eventually results.

Our present study compared the degree of adhesion formation associated with the use of chromic catgut (often recommended because of its perceived more intense tissue reactivity) and polypropylene (a relatively inert suture material) with respect to the degree of adhesion formation associated with their use in pexy procedures. The influence of species/breed factor was removed by the use of dogs of the same breed and litter.

Our findings revealed no difference in the gross evaluation scores of pexy sites in both chromic catgut and polypropylene sutured specimens. There was a consistent but gradual increase in the degree of adhesion formed in both groups from day 7 to day 30 post operative evaluation period.
Similarly, the degree of pexy dehiscence scores over time was comparable for both groups. Histologic evaluation showed no significant difference $(\mathrm{P}>0.05)$ but a gradual increase in the degree of inflammatory and fibroblastic indicators from day 7 to day 30 in all animals for both chromic catgut and polypropylene sutured pexies. These observations agree with findings of Rochat et al. (1996).

The study has also shown that chromic catgut caused mild to moderate tissue inflammatory response comparable to that elicited by polypropylene and that the response did not appear to be breed dependent as earlier posited by some authors (Van Winkle et al., 1975; Lawrie et al., 1960; Wood et al.), rather the major determinant of the quality of adhesion formed in our own opinion, seem to be the interplay between fibrin formation and its lysis by plasmin, an evident that occurs within the first 7-10 days after surgery.

The balance can be tipped towards increased fibrin formation by the choice of an appropriate suture material. Our findings from this study seem to suggest that polypropylene appear to cause more intense inflammatory and cellular reactions than chromic catgut within the first 7 days of healing. This observation is corroborated by the reports of some previous workers (Uff et al., 1995; Ajadi et al., 2006) and is attributed to the greater ability of polypropylene to activate immune competent cells more than chromic catgut due to greater interaction between the soluble factors forming the suture material and immune competent cells.

Considering the superior strength, better handling ability and knot security and safety, we recommend that polypropylene be preferred to chromic catgut for procedures in which adhesion formation is desired.

AKINRINMADE, J. F. \& LAWAL, A. O. Evaluación macroscópica e histológica de las adherencias abdominales asociadas a enteropexias suturadas con catgut crómico y polipropileno en perros. Int. J. Morphol., 28(4):1221-1225, 2010.

RESUMEN: Fueron evaluados los patrones macroscópicos e histológicos de las adherencias abdominales formadas por el uso de catgut crómico y materiales de sutura de polipropileno. Los exámenes macroscópicos e histológicos no revelaron diferencias significativas $(p>0,05)$ en el grado de adherencias observadas en los sitios de la enteropexia en ambos materiales de sutura. El uso de suturas de polipropileno con mejores cualidades debe ser considerado en lugar del catgut cromado para procedimientos en los que la adherencia en el perro es deseada.

PALABRAS CLAVE: Adhesión; Catgut crómico; Polipropileno; Eneropexy. 


\section{REFERENCES}

Ajadi, R. A.; Oloko, T. O.; Oni, S. O. \& Akinrinmade, J. F. A comparison of two suture materials in the closure of a pyloric incision in dogs. Folia Vet., 50:154-6, 2006.

Archibald, J. Textbook of Canine Surgery. $4^{\text {th }}$ ed. Santa Barbara, California, American Veterinary Publishing Inc., 1984.

Baxter, G. M. Intraabdominal adhesion in horses. Compend. Contin. Educ. Pract. Vet., 13:1587-98, 1991.

Bellinger, C. R. Sutures: Part I. The purpose of sutures and available suture materials. Comp. Cont. Educ. Pract. Vet., 4:507-15, 1982.

Bennett R. G. Selection of wound closure materials. J. Am. Acad. Dermatol., 18:619-37, 1988.

Booth, H. W. Selecting suture materials for small animal surgery. Compend. Contin. Educ. Pract. Vet., 20:15562, 1988.

Crowe, D. T. \& Bjorling, D. E. Peritoneum and abdominal cavity. In: Slatter, D. J. (Ed.). Small Animal Surgery. Philadelphia, W. B. Saunders, 1993.

diZerega, G. S. Biochemical events in peritoneal tissue repair. Eur. J. Surg. Suppl., 577:10-6, 1997.

Ellis, H. The causes and prevention of intestinal adhesions. Br. J. Surg., 69:241-3, 1982.

Henderson, R. A. Adhesion formation. In: Bojrab, M. J. (Ed.) Disease mechanisms in small animal surgery. $2^{\text {nd }}$ ed. Philadelphia, Lea and Febiger, 1993. pp.113-7.

Knightly, J. J.; Agostino, D. \& Cliffton, E. E. The effect of fibrinolysin and heparin on the formation of peritoneal adhesions. Surgery, 52:250-8, 1962.

Lawrie, P.; Angus, G. F. \& Reese, A. J. The absorption of surgical catgut. II. The influence of size. Br. J. Surg., 47:551-5, 1960.

Liakakos, T.; Thomakos, N.; Fine, P. M.; Dervenis, C. \& Young, R. L. Peritoneal adhesions: etiology, pathophysiology, and clinical significance. Recent advances in prevention and management. Dig. Surg., 18:260-73, 2001.
Lipowitz, A. J. \& Schenk, M. P. Surgical approaches to the abdominal and thoracic viscera of the dog and cat. Vet. Clin. North Am. Small Anim. Pract., 9:169-94, 1979.

Monk, B. J.; Berman, M. L. \& Montz, F. J. Adhesions after extensive gynecologic surgery: clinical significance, etiology, and prevention. Am. J. Obstet. Gynecol., 170:1396-403, 1994.

Rochat, M. C.; Lin, J.; Pope, E. R.; Carson, W. L.; WagnerMann, C. C. \& Pace, L. W. Comparison of the degree of abdominal adhesion formation associated with chromic catgut and polypropylene suture materials. Am. J. Vet. Res., 57:943-7, 1996.

Uff, C. R.; Scott, A. D.; Pockley, A. G. \& Phillips, R. K. Influence of soluble suture factors on in vitro macrophage function. Biomaterials, 16:355-60, 1995.

Van Winkle, W. Jr.; Hastings, J. C.; Barker, E.; Hines, D. \& Nichols, W. Effect of suture materials on healing skin wounds. Surg. Gynecol. Obstet., 140:7-12, 1975.

Wood, D. S.; Collins, J. E. \& Walshaw, R. Tissue reaction to nonabsorbable suture materials in the canine linea alba: a histological evaluation. J. Am. Anim. Hosp. Assoc., 20:39-44, 1984.

\section{Correspondence to:}

Dr. J. F. Akinrinmade

Department of Veterinary Surgery

Faculty of Veterinary Medicine

University of Ibadan

NIGERIA

Telephone: 234-802-3255-051

Email: fadeyemi akinrinmade@yahoo.com

Received: 25-09-2009

Accepted: 25-05-2010 
